\title{
Large-area solid oxide cells with La0.6Sr0.4CoO3- infiltrated oxygen electrodes for electricity generation and hydrogen production
}

Tong, Xiaofeng; Ovtar, Simona; Brodersen, Karen; Hendriksen, Peter Vang; Chen, Ming

Published in:

Journal of Power Sources

Link to article, DOI:

10.1016/j.jpowsour.2020.227742

Publication date:

2020

Document Version

Peer reviewed version

Link back to DTU Orbit

Citation (APA):

Tong, X., Ovtar, S., Brodersen, K., Hendriksen, P. V., \& Chen, M. (2020). Large-area solid oxide cells with $\mathrm{La} \mathrm{Sr}_{\mathrm{CoO}}$ infiltrated oxygen electrodes for electricity generation and hydrogen production. Journal of Power Sources, 3 451, [227742]. https://doi.org/10.1016/j.jpowsour.2020.227742

\section{General rights}

Copyright and moral rights for the publications made accessible in the public portal are retained by the authors and/or other copyright owners and it is a condition of accessing publications that users recognise and abide by the legal requirements associated with these rights.

- Users may download and print one copy of any publication from the public portal for the purpose of private study or research.

- You may not further distribute the material or use it for any profit-making activity or commercial gain

- You may freely distribute the URL identifying the publication in the public portal 


\title{
Large-area solid oxide cells with $\mathrm{La}_{0.6} \mathrm{Sr}_{0.4} \mathrm{CoO}_{3-\delta}$
}

\section{infiltrated oxygen electrodes for electricity}

\section{generation and hydrogen production}

Xiaofeng Tong, Simona Ovtar, Karen Brodersen, Peter Vang Hendriksen, Ming Chen*

Department of Energy Conversion and Storage, Technical University of Denmark, Frederiksborgvej 399, Roskilde, Denmark

*Corresponding author: minc@dtu.dk

\begin{abstract}
Infiltration is an effective way to improve the performance of the oxygen electrode for solid oxide cells (SOCs). Most studies on infiltrated SOCs are carried out on button cells with a small active area. Here, we report on the preparation of large-area fuel-electrode-supported SOCs with a $\mathrm{La}_{0.6} \mathrm{Sr}_{0.4} \mathrm{CoO}_{3-\delta}$ (LSC) infiltrated gadolinia-doped ceria (CGO) oxygen electrode. The electrochemical performance of the resulting SOCs is examined at $4 \times 4 \mathrm{~cm}^{2}$ level (active area). The cell delivers a power density of $1.08 \mathrm{~W} \mathrm{~cm}^{-2}$ at $0.6 \mathrm{~V}$ and $750{ }^{\circ} \mathrm{C}$ in fuel cell mode with high fuel and oxygen utilization of 52 and $57 \%$, respectively; in electrolysis mode, the current density reaches $1.07 \mathrm{~A} \mathrm{~cm}^{-2}$ at $1.3 \mathrm{~V}$ and $750{ }^{\circ} \mathrm{C}$ with a steam utilization of $60 \%$. Additionally, the
\end{abstract}


influence of feed gas composition on cell performance and the short-term durability of the cell in electrolysis mode are studied. Electrochemical impedance spectroscopy (EIS) results and the post-test microstructural characterization demonstrate that there is no visible degradation of the LSC infiltrated CGO oxygen electrode after the durability test. These results highlight the potential of large-scale production of high-performance SOCs by designing nanostructured electrode via infiltration.

Keywords: Reversible solid oxide cell; Oxygen electrode; Infiltration; Nanostructure; Durability 


\section{Introduction}

Affordable large-scale energy storage is essential for a sustainable energy future with a rising share of solar and wind-based intermittent electricity generation [1]. Solid oxide cells (SOCs) is a promising technology in this context. They can be operated either in electrolysis mode to convert surplus electricity from these renewable sources into chemical energy stored in various fuels such as $\mathrm{H}_{2}$ and/or $\mathrm{CO}$, or in fuel cell mode to generate electricity using the fuels produced [2-4]. One of the key factors limiting the performance of SOCs is the rate of the oxygen electrode reaction processes, i.e., the oxygen reduction reaction (ORR) in fuel cell mode and the oxygen evolution reaction (OER) in electrolysis mode, particularly at temperatures $\leq 750{ }^{\circ} \mathrm{C}$. The most well studied oxygen electrode material is strontium-doped lanthanum manganite (LSM)/yttria-stabilized zirconia (YSZ) composite. However, SOCs with LSM/YSZ electrodes have limited performance at reduced temperatures; at $750{ }^{\circ} \mathrm{C}$, most such cells were reported to show power densities of $0.3-0.65 \mathrm{~W} \mathrm{~cm}^{-2}$ at a voltage of $0.7 \mathrm{~V}$ in fuel cell mode and current densities of 0.2-0.5 $\mathrm{A} \mathrm{cm}^{-2}$ at $1.3 \mathrm{~V}$ in electrolysis mode [5-9].

Accordingly, mixed ionic-electronic conducting (MIEC) oxides, such as $\mathrm{La}_{0.6} \mathrm{Sr}_{0.4} \mathrm{Co}_{0.2} \mathrm{Fe}_{0.8} \mathrm{O}_{3-\delta}$ (LSCF) [10, 11], $\mathrm{La}_{0.6} \mathrm{Sr}_{0.4} \mathrm{CoO}_{3-\delta}$ (LSC) [12], $\mathrm{Sm}_{0.5} \mathrm{Sr}_{0.5} \mathrm{CoO}_{3-\delta}$ (SSC) [13], $\quad \mathrm{Ba}_{0.5} \mathrm{Sr}_{0.5} \mathrm{Co}_{0.8} \mathrm{Fe}_{0.2} \mathrm{O}_{3-\delta}(\mathrm{BSCF}) \quad$ [14], $\quad \operatorname{PrBa}_{0.5} \mathrm{Sr}_{0.5} \mathrm{Co}_{1.5} \mathrm{Fe}_{0.5} \mathrm{O}_{5+\delta} \quad$ (PBSCF) [15], $\mathrm{Pr}_{2} \mathrm{NiO}_{4+\delta}$ (PNO) [16] and $\operatorname{Pr}_{6} \mathrm{O}_{11}$ [17] have been employed as alternative oxygen electrode materials, resulting in improved performance. Solution infiltration, also known as impregnation, has drawn increasing interests for preparing these MIEC type electrodes [18-21]. In the infiltration process the active electrocatalysts are introduced into a porous backbone at relatively low temperatures. Typically, the maximum firing temperature for the infiltrated electrode is now 
the temperature of cell operation. Issues of chemical reactivity and thermal expansion mismatch of such MIEC oxides with the other cell components can be alleviated. The resulting electrodes with nano-scale catalysts have shown improved catalytic activity for the ORR/OER. For example, a power density of $0.78 \mathrm{~W} \mathrm{~cm}^{-2}$ at $0.7 \mathrm{~V}$ in fuel cell mode and a current density of $0.98 \mathrm{~A} \mathrm{~cm}^{-2}$ at 1.3 V in electrolysis mode were reported on a cell with LSCF infiltrated YSZ oxygen electrode at $750{ }^{\circ} \mathrm{C}$ [22]. Even better performance was reported on a cell using LSCF/gadolinia-doped ceria (CGO) composite electrode infiltrated with SSC nano-catalysts, exhibiting a power density of $1.39 \mathrm{~W} \mathrm{~cm}^{-2}$ at $0.7 \mathrm{~V}$ in fuel cell mode and a current density of $1.80 \mathrm{~A} \mathrm{~cm}^{-2}$ at $1.3 \mathrm{~V}$ in electrolysis mode [23].

However, most reports of infiltrated SOCs were carried out on laboratory-scale button size cells with active areas less than $2 \mathrm{~cm}^{2}$. The performance of such button cells does not necessarily represent the performance of corresponding large-area, commercially relevant cells due to complexities related to the scale up of the manufacture and the influence of operating conditions such as increased gas utilization and non-isothermal operation. There have been only limited reports of successful manufacture of large-area cells using infiltration. In one exception, Jiang et al. reported a fuel-electrode-supported planar SOC with an active area of $9 \times 9 \mathrm{~cm}^{2}$ and an LSCF infiltrated YSZ oxygen electrode [24]. This SOC was investigated for fuel cell operation, displaying a power density of $0.42 \mathrm{~W} \mathrm{~cm}^{-2}$ at $0.7 \mathrm{~V}$ and $750{ }^{\circ} \mathrm{C}$. More recently, we have developed two types of fuel-electrode-supported SOCs in size of $13 \times 13 \mathrm{~cm}^{2}$ with either an LSC infiltrated YSZ oxygen electrode or a $\mathrm{LaNi}_{0.6} \mathrm{Co}_{0.4} \mathrm{O}_{3-\delta}$ (LNC) infiltrated $\mathrm{YSZ}$ oxygen electrode and evaluated their performance for fuel cell operation at $4 \times 4 \mathrm{~cm}^{2}$ level (active area) [25]. Even though a CGO coating was infiltrated into the YSZ backbone prior to infiltrating LNC electrocatalysts, the formation of poorly conducting zirconate phases $\left(\mathrm{La}_{2} \mathrm{Zr}_{2} \mathrm{O}_{7}\right.$ or $\left.\mathrm{SrZrO}_{3}\right)$ at the 
interface between the electrocatalyst and YSZ backbone (where the CGO covering is not complete) was observed for $1300 \mathrm{~h}$ operation in fuel cell mode at $700{ }^{\circ} \mathrm{C}, 0.5 \mathrm{~A} \mathrm{~cm}^{-2}$. In this work, $12.5 \times 12.5 \mathrm{~cm}^{2}$ fuel-electrode-supported half cells with porous CGO backbones at the oxide electrode side are produced by scalable and cost-effective processes of tape-casting, lamination, and co-sintering, and then an LSC precursor solution is infiltrated into the CGO backbones to prepare nanostructured LSC-CGO oxygen electrode. A CGO backbone is applied instead of YSZ as CGO has good chemical compatibility with most of the preferred perovskite electrocatalysts (including LSC) and higher ionic conductivity than YSZ. The prepared planar SOCs are investigated at $4 \times 4 \mathrm{~cm}^{2}$ level (active area) both in fuel cell mode and electrolysis mode. The durability of the cell in the electrolysis mode is investigated under a constant current density of $0.5 \mathrm{~A} \mathrm{~cm}^{-2}$ at $750{ }^{\circ} \mathrm{C}$.

\section{Experimental}

\subsection{Cell preparation}

The $12.5 \times 12.5 \mathrm{~cm}^{2}$ fuel-electrode-supported cells with a configuration $\mathrm{NiO} / \mathrm{YSZ}$ support $\mathrm{NiO} / \mathrm{YSZ}$ fuel electrode | YSZ electrolyte | CGO barrier | CGO backbone were produced by laminating and co-sintering tape-cast green tapes at $1315{ }^{\circ} \mathrm{C}$. The tape-cast slurries were prepared by two steps ball milling. In the first step, the ceramic powders were dispersed and milled in Ethanol with PVP as dispersant. The ball milling was performed in a plastic container with zirconia milling balls for 3 days. In the second step, PVB binder solution was added and mixed for 1 day. The green tapes of $\mathrm{NiO} / \mathrm{YSZ}$ support, $\mathrm{NiO} / \mathrm{YSZ}$ fuel electrode and CGO backbone were prepared by single layer tape-casting while tapes of YSZ electrolyte and CGO 
barrier were prepared via a multilayer tape casting (MTC) process [26]. The CGO backbone tape was prepared with the addition of $60-70 \%$ pyrolyseable pore formers in the tape-cast slurry to obtain sufficient porosity after sintering. The volume ratio of Ni to YSZ in the Ni/YSZ support and electrode was controlled to be $40 / 60$ after the reduction of $\mathrm{NiO}$ [27].

Afterwards, LSC catalyst was coated on the internal surfaces of the porous CGO backbone via the infiltration technique, as reported previously $[21,25] . \mathrm{La}\left(\mathrm{NO}_{3}\right)_{3} \cdot 6 \mathrm{H}_{2} \mathrm{O}, \mathrm{Sr}\left(\mathrm{NO}_{3}\right)_{2} \cdot 4 \mathrm{H}_{2} \mathrm{O}$, and $\mathrm{Co}\left(\mathrm{NO}_{3}\right)_{2} \cdot 6 \mathrm{H}_{2} \mathrm{O}$ were dissolved into deionized water to prepare the corresponding nitrate solutions, respectively. $\mathrm{La}\left(\mathrm{NO}_{3}\right)_{3}, \mathrm{Sr}\left(\mathrm{NO}_{3}\right)_{2}$, and $\mathrm{Co}\left(\mathrm{NO}_{3}\right)_{3}$ solutions were mixed in a molar ratio of 3:2:5 to obtain 0.5 M LSC precursor solution. Note that the surfactant Pluoronic ${ }^{\circledR}$ P123 (1.7 wt. \%) was added into the LSC precursor solution to improve wetting/penetration of the structure, thus ensuring a uniform dispersion of infiltrate [25]. The LSC solution was dropped onto the surface of the CGO backbone and spread over the entire surface. The solution sucked into the pores of the backbone driven by capillary forces. A sufficient amount of solution was dropped to ensure that the pores of the backbone were completely filled. The surplus solution was removed from the surface with a sponge. The infiltrated samples were then calcinated at 350 ${ }^{\circ} \mathrm{C}$ in air for $15 \mathrm{~min}$ with a heating/cooling rate of $5{ }^{\circ} \mathrm{C} \min ^{-1}$. The infiltration/calcination processes were repeated 9 times to get a loading of $\sim 1300 \mathrm{mg}$ of LSC catalysts per $1 \mathrm{~cm}^{3}$ CGO scaffold. After the infiltration, the cells were cut into pieces of $5.3 \times 5.3 \mathrm{~cm}^{2}$ to fit the in-house constructed cell test houses. Finally, an LSC layer in size of $4 \times 4 \mathrm{~cm}^{2}$ was screen printed onto the oxygen electrode to enhance the current collection.

\subsection{Electrochemical characterization}


The electrochemical performance and durability of the prepared cells were investigated using inhouse constructed test rigs. In each test, a cell was mounted onto an alumina housing and sealed with a gold frame, as described in previous work [28]. The cells were heated to $800{ }^{\circ} \mathrm{C}$ with a heating rate of $1{ }^{\circ} \mathrm{C} \min ^{-1}$ and with pure Ar fed to the fuel electrode and dry air to the oxygen electrode. Afterwards, the cells were held at $800{ }^{\circ} \mathrm{C}$ for $4 \mathrm{~h}$ with the fuel electrode first fed with $9 \% \mathrm{H}_{2}-91 \%$ Ar for $2 \mathrm{~h}$, followed by another $2 \mathrm{~h}$ in $4 \% \mathrm{H}_{2} \mathrm{O}-96 \% \mathrm{H}_{2}$ to fully reduce all $\mathrm{NiO}$ to $\mathrm{Ni}$ and form a percolating network. Meanwhile, the oxygen electrode was treated with air to enable the infiltrates to form the desired LSC crystalline phase. The electrochemical performance of the cells was evaluated at $800-700{ }^{\circ} \mathrm{C}$ under varying gas feeds to the electrodes, but the flow rates of gases in the fuel and oxygen electrodes were kept at $241 \mathrm{~h}^{-1}$ and $501 \mathrm{~h}^{-1}$, respectively. Electrochemical impedance spectroscopy (EIS) measurements were conducted using a Solartron 1255 frequency response analyzer in combination with a measurement resistor, at frequencies from 0.0968 to $96850 \mathrm{~Hz}$ with an amplitude of $3.75 \mathrm{~mA} \mathrm{~cm}^{-2}$. The durability of the cell was evaluated in electrolysis mode at $750{ }^{\circ} \mathrm{C}$ under a constant current density of $0.5 \mathrm{~A} \mathrm{~cm}^{-2}$, with $13.41 \mathrm{~h}^{-1} 90 \% \mathrm{H}_{2} \mathrm{O}-10 \% \mathrm{H}_{2}$ fed to the fuel electrode and $50 \mathrm{l} \mathrm{h}^{-1}$ pure $\mathrm{O}_{2}$ to the oxygen electrode. EIS data were recorded every $20 \mathrm{~h}$ during the durability test under the current of $0.5 \mathrm{~A} \mathrm{~cm}^{-2}$. All of EIS data analyses were carried out using the Python-based software Ravdav [29].

\subsection{Microstructure characterization}

The cell structure was examined using scanning electron microscopy (SEM) in a Zeiss Merlin microscope. Both polished and fractured cross-sections of the cells were prepared for SEM characterization, corresponding to the SEM micrographs shown in Fig. 1 and Fig. 8, respectively. SEM image analysis was carried out with ImageJ software. In order to check the phase composition of the infiltrates deposited on the CGO backbone, powders synthesized by 
calcinating the above LSC infiltrate solution at $800{ }^{\circ} \mathrm{C}$ for $4 \mathrm{~h}$ were examined at room temperature using X-ray diffraction (XRD, Bruker D8 Rigaku, CuK $\alpha$ radiation) with a scanning range of $20-80^{\circ}$ and a step size of $0.01^{\circ}$.

\section{Results and discussion}

\subsection{Microstructure}

Fig. 1a and Fig. S1 show the typical cross-sectional SEM micrographs of the fuel-electrodesupported cell prior to infiltration of LSC catalysts. The cell consists of a Ni/YSZ support ( 300 $\mu \mathrm{m})$, a Ni/YSZ fuel electrode $(\sim 15 \mu \mathrm{m})$, a YSZ electrolyte $(\sim 5 \mu \mathrm{m})$, a CGO barrier layer $(\sim 6$ $\mu \mathrm{m})$, and a porous CGO backbone $(\sim 25 \mu \mathrm{m})$. There is good adherence between different layers as no obvious delamination or crack is observed. The YSZ electrolyte is fully dense while some closed pores are observed in the CGO barrier layer. The CGO backbone for infiltration has a uniform porous microstructure with a porosity of $\sim 55 \%$ and an average pore size of $\sim 1.3 \mu \mathrm{m}$, estimated based on counting black and gray pixels of the micrograph, which refer to pores and CGO grains, respectively (Fig. 1a and 1b). 

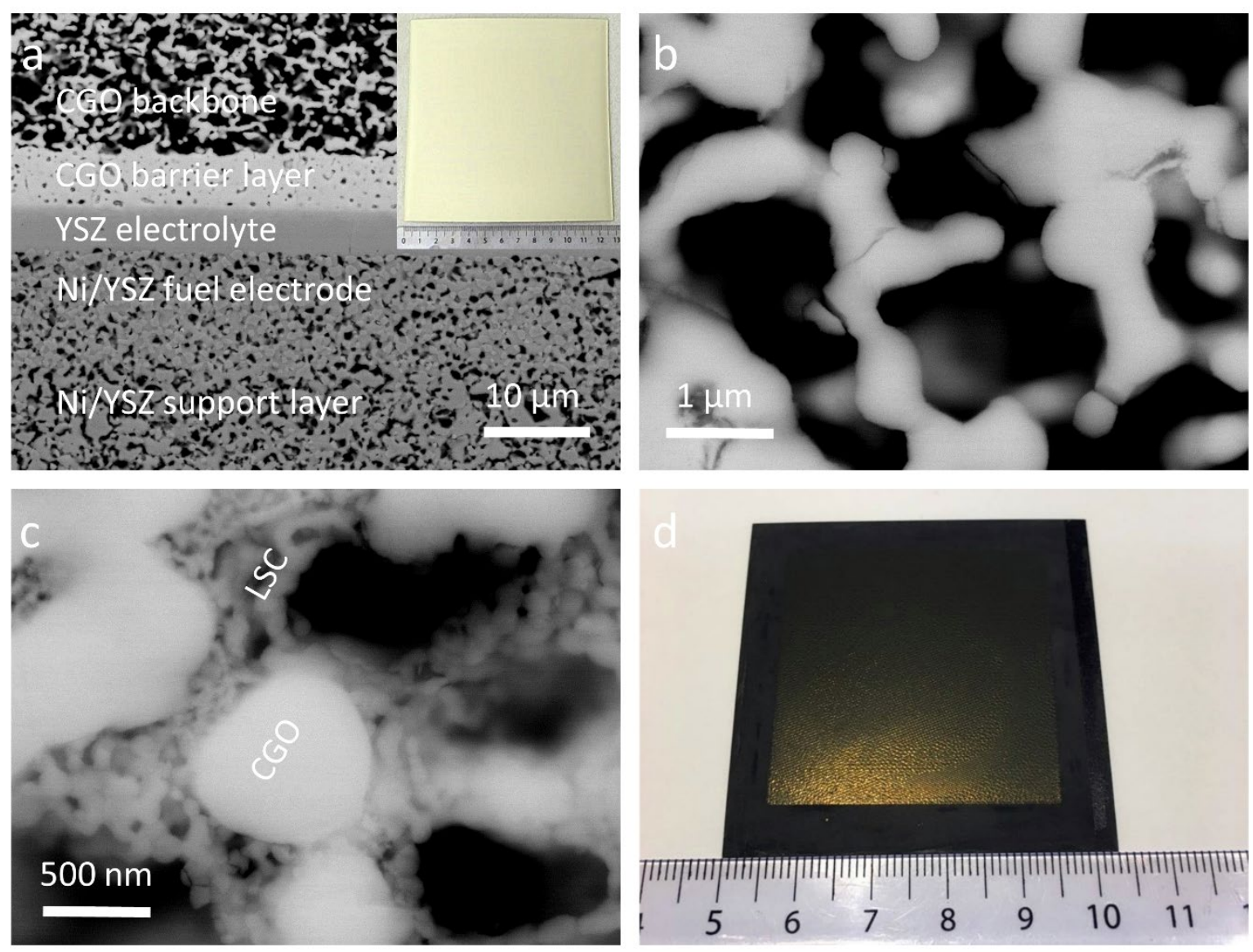

Fig. 1. Cross-sectional SEM images of (a) a fuel electrode-supported cell prior to the infiltration of LSC (inset showing the photograph of this cell in size of $12.5 \times 12.5 \mathrm{~cm}^{2}$ ), (b) porous CGO backbone, and (c) CGO backbone infiltrated with LSC catalysts. (d) Photograph showing the asprepared planar cell for testing.

The LSC infiltrated CGO oxygen electrode is prepared by infiltration of LSC catalysts and calcination at $800{ }^{\circ} \mathrm{C}$, and its microstructure is shown in Fig. 1c and Fig. S2, where the interconnected and nanoporous LSC coatings are well deposited on the internal surfaces of the porous CGO backbone. Formation of LSC in the coatings is confirmed by XRD pattern of powders, synthesized by calcinating the infiltrate solution at $800{ }^{\circ} \mathrm{C}$ (Fig. 2). In addition to LSC, second phases including $\left(\mathrm{La}_{2-\mathrm{x}} \mathrm{Sr}_{\mathrm{x}}\right) \mathrm{CoO}_{4}, \mathrm{SrCO}_{3}$, and $\mathrm{Co}_{3} \mathrm{O}_{4}$ were detected. Similar secondary 
phases of LSC infiltration have also been observed by Samson et al. [30], even though a higher calcinating temperature of $900{ }^{\circ} \mathrm{C}$ was applied. Note that secondary phases of $\left(\mathrm{La}_{2-\mathrm{x}} \mathrm{Sr}_{\mathrm{x}}\right) \mathrm{CoO}_{4}$ [31] and $\mathrm{Co}_{3} \mathrm{O}_{4}$ [30] have been demonstrated with electrochemical activity when applied as catalysts for oxygen electrodes. Hence secondary phases may not necessarily be detrimental to the electrochemical reactions. In addition, a 100\% phase pure LSC infiltrate may not necessarily provide the best electrochemical performance if this has to be achived via calcination at high temperature with coarsened catalyst particles. In the current work, a calcination temperature of $800{ }^{\circ} \mathrm{C}$ was eventually chosen based on the findings from Samson et al. [30]. Fig. 1d shows a photograph of the as-prepared planar cell that has been cut into the size of $5.3 \times 5.3 \mathrm{~cm}^{2}$, with a screen-printed $4 \times 4 \mathrm{~cm}^{2}$ LSC contact layer on top of the LSC infiltrated CGO oxygen electrode.

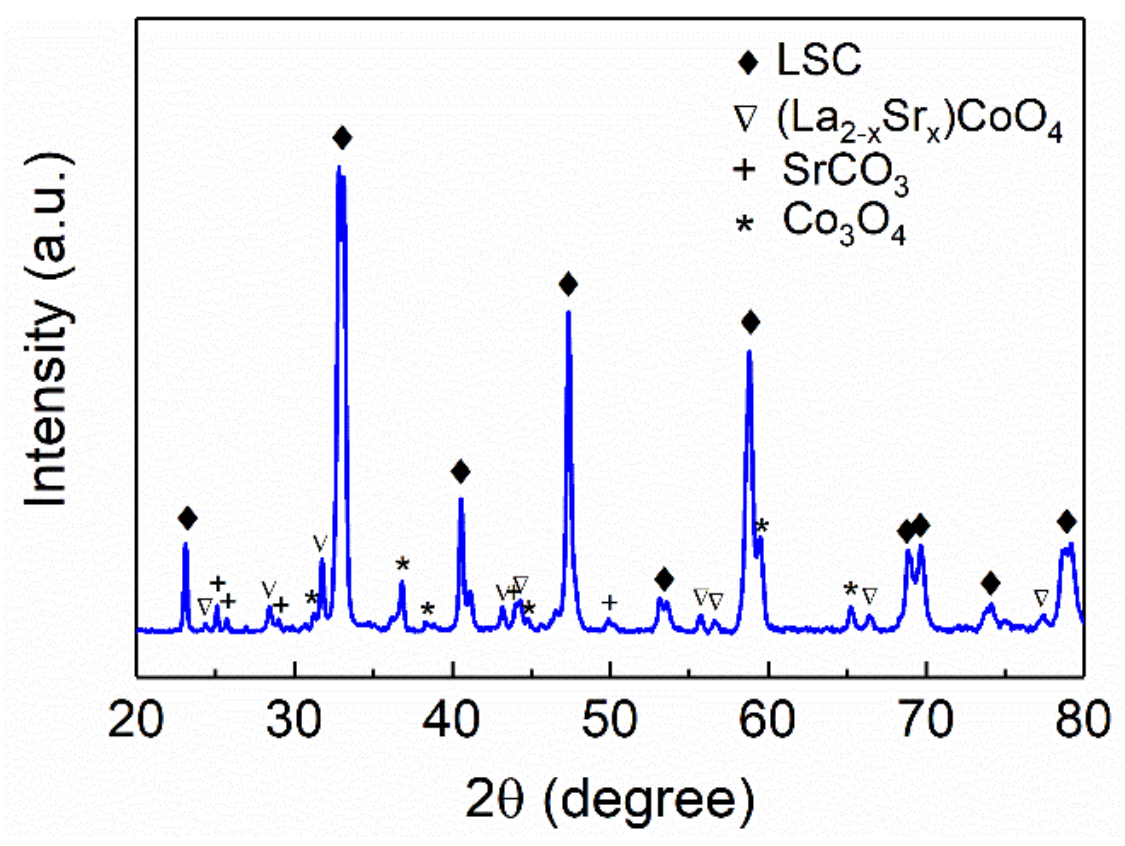

Fig. 2. XRD pattern of the LSC powders calcinated at $800{ }^{\circ} \mathrm{C}$.

3.2. Electrochemical performance 
The electrochemical performance of the as-prepared cells was evaluated both in fuel cell mode and electrolysis cell mode. The active area of the cells is $4 \times 4 \mathrm{~cm}^{2}$ (the edges are used for sealing, as described in Experimental). Fig. 3a shows typical polarization curves of cell voltage and power density versus current density ( $I-V-P$ curves) of fuel cell operation, measured at $700-800$ ${ }^{\circ} \mathrm{C}$ with $4 \% \mathrm{H}_{2} \mathrm{O}-96 \% \mathrm{H}_{2}$ fed to the fuel electrode and dry air to the oxygen electrode. The open circuit voltages (OCVs) range between $1.050 \mathrm{~V}$ at $800{ }^{\circ} \mathrm{C}$ and $1.069 \mathrm{~V}$ at $700{ }^{\circ} \mathrm{C}$, and are within $35 \mathrm{mV}$ off the calculated Nernst potentials $\left(1.085 \mathrm{~V}\right.$ at $800{ }^{\circ} \mathrm{C}$ and $1.104 \mathrm{~V}$ at $\left.700{ }^{\circ} \mathrm{C}\right)$. Under a voltage output of $0.6 \mathrm{~V}$, the cell delivers power densities of $1.34,1.08$, and $0.70 \mathrm{~W} \mathrm{~cm}^{-2}$ at 800 , 750 , and $700{ }^{\circ} \mathrm{C}$, respectively. Unlike most of the previous SOC studies, in which the power densities are reported on button cells with active areas less than $2 \mathrm{~cm}^{2}$ and gas utilization lower than $10 \%$, the here-reported power densities are accompanied with significant fuel and oxygen utilization, e.g., 65 and $71 \%$ at $800{ }^{\circ} \mathrm{C}, 52$ and $57 \%$ at $750{ }^{\circ} \mathrm{C}$, and 34 and $37 \%$ at $700{ }^{\circ} \mathrm{C}$, respectively (Fig. 2b). A high gas utilization is required for practical application and leads to lower power out than with negligible utilization due to the loss of Nernst potential along the fuel flow. The effect of fuel utilization on cell performance was further illustrated by feeding $\mathrm{H}_{2} \mathrm{O}-\mathrm{H}_{2}$ mixtures with varying $\mathrm{H}_{2} \mathrm{O}$ to $\mathrm{H}_{2}$ ratios. The $\mathrm{OCV}$ decreases from 1.060 to $0.947 \mathrm{~V}$ with decreasing $\mathrm{H}_{2}$ content from $96 \%$ to $50 \%$ in accordance with the tendency of the calculated Nernst potentials that decreasing from $1.095 \mathrm{~V}$ to $0.957 \mathrm{~V}$ (Fig. 3c). At a voltage of $0.6 \mathrm{~V}$, power densities decrease from 1.08 to $0.78 \mathrm{~W} \mathrm{~cm}^{-2}$, corresponding to a fuel utilization of $52 \%$ and $72 \%$, respectively (Fig. 3d). 

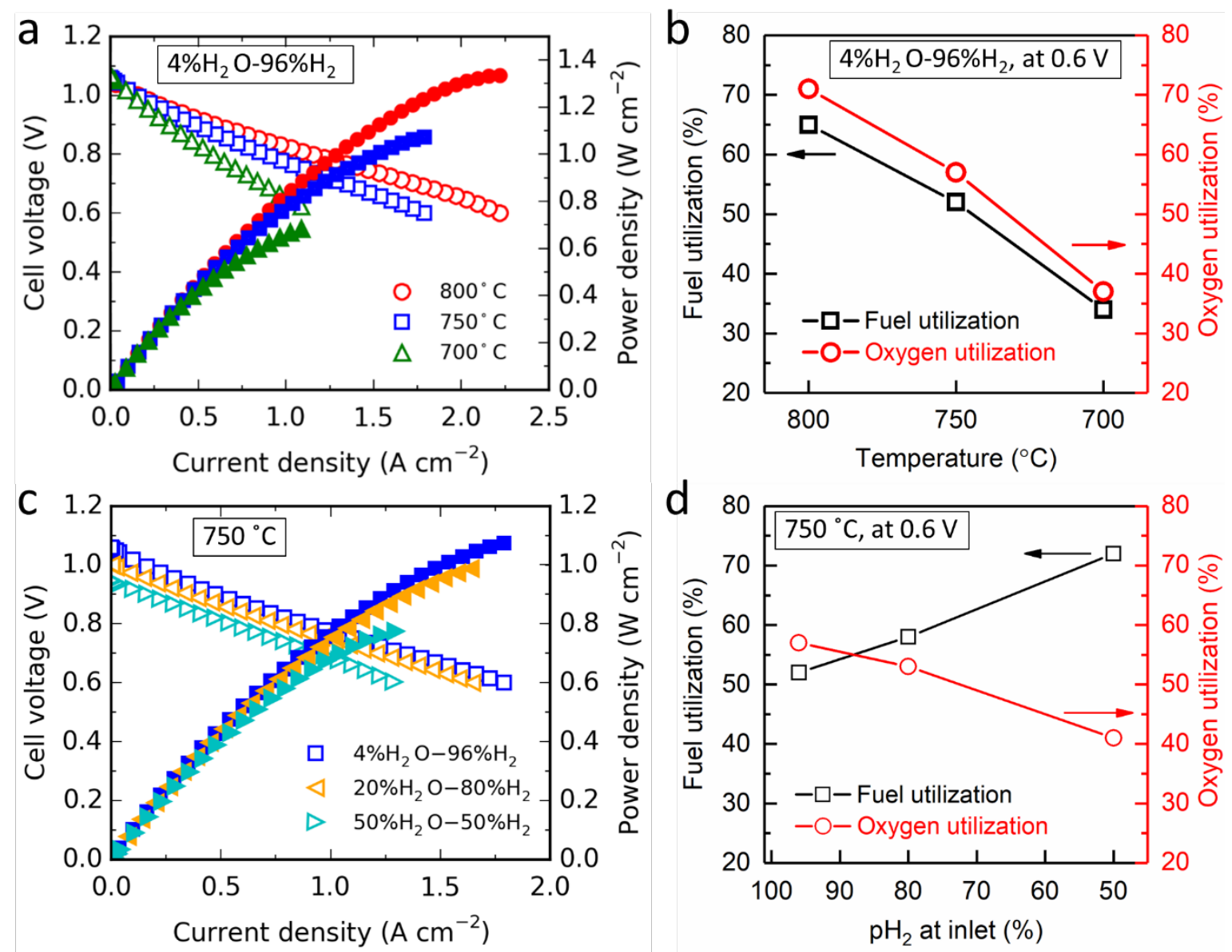

Fig. 3. Performance in fuel cell mode. Voltage and power density versus current density measured (a) at different temperatures with $4 \% \mathrm{H}_{2} \mathrm{O}-96 \% \mathrm{H}_{2}$ fed to the fuel electrode and dry air to the oxygen electrode, and (c) at $750{ }^{\circ} \mathrm{C}$ with different $\mathrm{H}_{2} \mathrm{O}-\mathrm{H}_{2}$ gas mixtures fed to the fuel electrode and dry air to the oxygen electrode. (b, d) Corresponding fuel utilization and oxygen utilization at an operating potential of $0.6 \mathrm{~V}$ on the performance shown in (a) and (c).

Fig. 4a shows the voltage versus current density $(I-V)$ curves in electrolysis mode for $\mathrm{H}_{2}$ production, measured at $700-800{ }^{\circ} \mathrm{C}$ with $50 \% \mathrm{H}_{2} \mathrm{O}-50 \% \mathrm{H}_{2}$ fed to the fuel electrode and dry air to the oxygen electrode. The OCVs at different temperatures are all within $10 \mathrm{mV}$ of the calculated Nernst potentials. At an electrolysis voltage of $1.3 \mathrm{~V}$, current densities of 1.37, 1.07, and $0.69 \mathrm{~A} \mathrm{~cm}^{-2}$ are obtained at 800,750 , and $700{ }^{\circ} \mathrm{C}$, respectively, which correspond to the $\mathrm{H}_{2}$ 
production rates of 9.53, 7.45, and $4.80 \mathrm{ml} \mathrm{min}^{-1} \mathrm{~cm}^{-2}$, respectively, calculated using Faraday's law. These $\mathrm{H}_{2}$ production rates are achieved with steam utilization of $76 \%, 60 \%$, and $38 \%$, respectively, and the hydrogen content in the outlet gas reaches $88 \%, 80 \%$, and $69 \%$. At $800{ }^{\circ} \mathrm{C}$, a significantly nonlinear increase in the voltage at high current densities is observed, which is attributed to the effect of growing concentration polarization because of the steam starvation in the fuel electrode under high steam utilization $[32,33]$.

The electrolysis performance was also investigated under different gas feeds to the fuel and oxygen electrodes at $750{ }^{\circ} \mathrm{C}$. As shown in Fig. 4 c, increasing the $\mathrm{H}_{2} \mathrm{O}$ content from $20 \%$ to $50 \%$ leads to a decrease in OCV of $54 \mathrm{mV}$. The cell exhibits a current density of $0.64 \mathrm{~A} \mathrm{~cm}^{-2}$ at $1.3 \mathrm{~V}$ with $20 \% \mathrm{H}_{2} \mathrm{O}-80 \% \mathrm{H}_{2}$ fed to the fuel electrode. This performance is strongly limited by the concentration polarization due to the high steam utilization of $86 \%$, and the corresponding hydrogen content in the outlet gas is as high as $97 \%$ (Fig. 4 d). By increasing $\mathrm{H}_{2} \mathrm{O}$ content to $50 \%$, the concentration polarization is significantly reduced, resulting in an increase in current density of $67 \%$ (i.e., $0.43 \mathrm{~A} \mathrm{~cm}^{-2}$ ) at $1.3 \mathrm{~V}$. Fig. $4 \mathrm{c}$ also shows that the $\mathrm{OCV}$ increases $25 \mathrm{mV}$ when the gas in the oxygen electrode is changed from air to pure $\mathrm{O}_{2}$, and the current density at $1.3 \mathrm{~V}$ has a slight increase of $2 \%$ (i.e., $0.02 \mathrm{~A} \mathrm{~cm}^{-2}$ ). Hence, the decreased driving force due to the increased OCV is fully compensated for by improved electrode performance in pure $\mathrm{O}_{2}$. One should note that in principle for technical use, $\mathrm{O}_{2}$ purge at the oxygen electrode is not likely to be a preferred mode of operation. Either no purge should be applied - "oxygen production mode" or for safety reasons steam, $\mathrm{N}_{2}$ purge could be considered depending on whether the produced oxygen will be used or discarded. The results show that electrolysis performance is more sensitive to the $\mathrm{H}_{2} \mathrm{O}$ content in the fuel electrode and the corresponding steam utilization and less sensitive to the 
oxygen content in the oxygen electrode, as expected both from the relative thickness of the electrodes and the form of the Nernst expression.
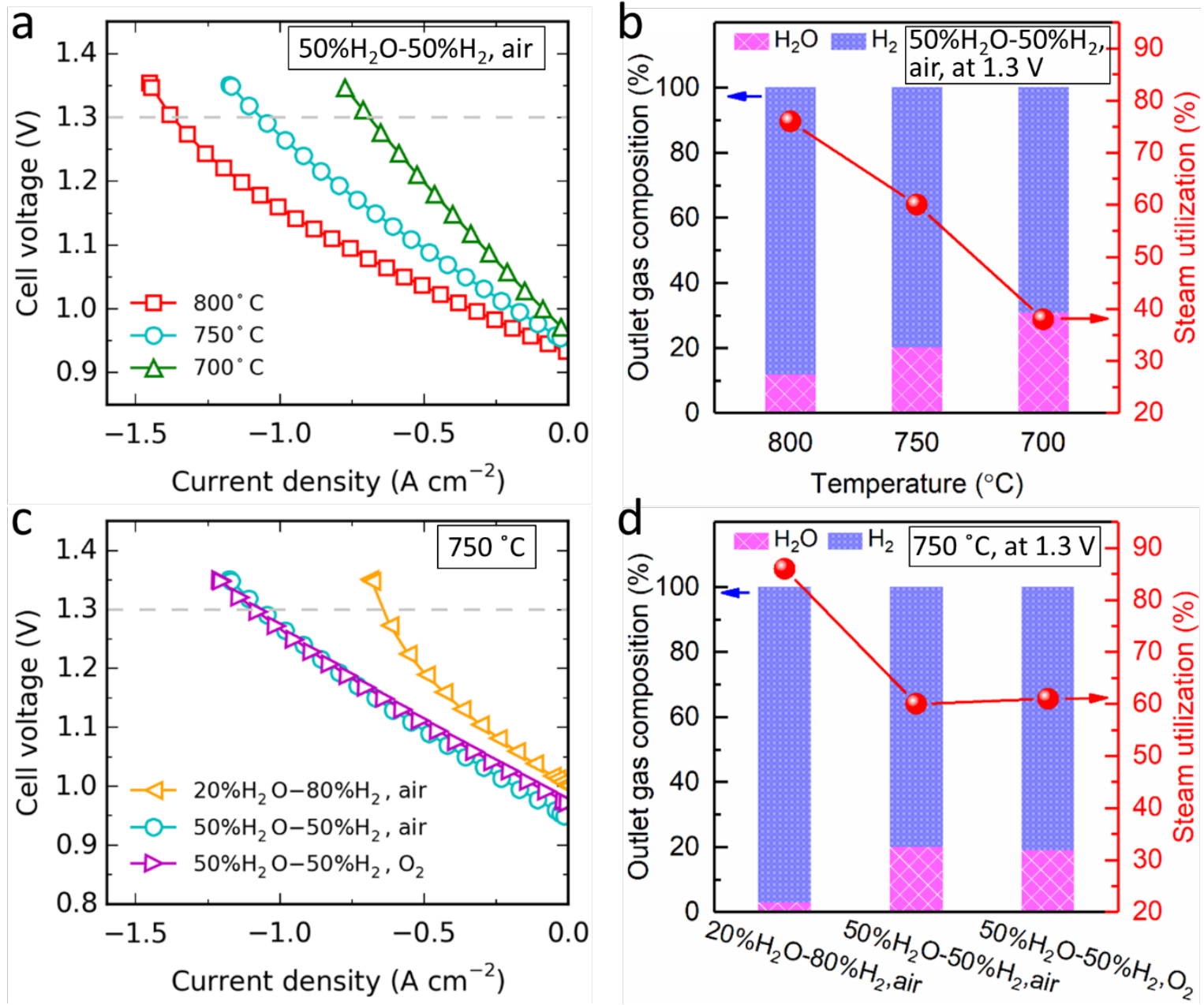

Fig. 4. Performance in electrolysis cell mode. Voltage versus current density measured (a) at different temperatures with $50 \% \mathrm{H}_{2} \mathrm{O}-50 \% \mathrm{H}_{2}$ fed to the fuel electrode and dry air to the oxygen electrode, and (c) at $750{ }^{\circ} \mathrm{C}$ with varying gas feeds to the electrodes. (b, d) Corresponding gas composition at the outlet and overall steam utilization at an operating potential of $1.3 \mathrm{~V}$ on the performance shown in (a) and (c). 
Fig. 5a-e shows the Nyquist plots of EIS data recorded under OCV condition in the temperature range of $700-800{ }^{\circ} \mathrm{C}$ with different gas feeds. The intercept with the real axis at high frequency in the Nyquist plot represents the ohmic resistance $\left(\mathrm{R}_{\mathrm{ohm}}\right)$, and the difference between the high and low frequency intercepts represents the total electrode polarization resistance $\left(R_{p}\right)$. $\mathrm{R}_{\mathrm{ohm}}$ is almost unaltered with the change of gas feeds, and they are around $0.11,0.16$, and $0.25 \Omega$ $\mathrm{cm}^{2}$ at 800,750 , and $700{ }^{\circ} \mathrm{C}$, respectively. These $\mathrm{R}_{\mathrm{ohm}}$ are much greater than the expected resistances for $5 \mu \mathrm{m}$ thick YSZ electrolyte and $6 \mu \mathrm{m}$ thick CGO barrier here. At $700{ }^{\circ} \mathrm{C}$, the observed $\mathrm{R}_{\mathrm{ohm}}$ of $0.25 \Omega \mathrm{cm}^{2}$ is 5 times the expected $\left(\sim 0.05 \Omega \mathrm{cm}^{2}\right)$ based upon the ionic conductivities of $0.02 \mathrm{~S} \mathrm{~cm}^{-1}$ for YSZ and $0.03 \mathrm{~S} \mathrm{~cm}^{-1}$ for CGO [34]. This can be attributed to the interdiffusion of elements at the YSZ electrolyte - CGO barrier interface during the cosintering process at $1315^{\circ} \mathrm{C}$ leading to the formation of solid solution phases with lower ionic conductivity [35-37]. Furthermore, $\mathrm{R}_{\mathrm{ohm}}$ actually constitute $29-40 \%$ and $56-60 \%$ of the overall resistances of the EIS data shown in Fig. 5a and 5c, respectively. These results suggest that there is room for further improvement of the cell performance by limiting the YSZ - CGO interdiffusion via, e.g., lowering the sintering temperature, or more preferably sintering the half-cell (NiO/YSZ support $\mid \mathrm{NiO} / Y S Z$ fuel electrode $\mid$ YSZ electrolyte) first and then sintering CGO barrier and porous CGO layer at lower temperature, such as $1200{ }^{\circ} \mathrm{C}$.

For $4 \% \mathrm{H}_{2} \mathrm{O}-96 \% \mathrm{H}_{2}$ fed to the fuel electrode and air to the oxygen electrode, the $\mathrm{R}_{\mathrm{p}}$ values are $0.26,0.30$, and $0.38 \Omega \mathrm{cm}^{2}$ at 800,750 , and $700{ }^{\circ} \mathrm{C}$, respectively (Fig. 5a). These $\mathrm{R}_{\mathrm{p}}$ values are lower than those of our previously reported Ni/YSZ fuel electrode supported cell with a thin YSZ electrolyte, a CGO barrier layer applied by pulsed vapor deposition (PVD), and a screen printed LSC/CGO oxygen electrode [38], showing $\mathrm{R}_{\mathrm{p}}$ values of $0.44 \Omega \mathrm{cm}^{2}$ at $750{ }^{\circ} \mathrm{C}$ and $0.59 \Omega$ $\mathrm{cm}^{2}$ at $700{ }^{\circ} \mathrm{C}$ under same gas conditions (Fig. S3). The $\mathrm{R}_{\mathrm{p}}$ values are also lower than many of 
those previously reported for other cells with $\mathrm{Ni} / \mathrm{YSZ}$ fuel electrodes and using different oxygen electrodes, e.g., $0.43 \Omega \mathrm{cm}^{2}$ at $750{ }^{\circ} \mathrm{C}$ for the commonly used LSCF/CGO composite [23], 0.78 $\Omega \mathrm{cm}^{2}$ at $700{ }^{\circ} \mathrm{C}$ for SSC infiltrated YSZ [39], and $0.44 \Omega \mathrm{cm}^{2}$ at $700{ }^{\circ} \mathrm{C}$ for $\mathrm{LaNi}_{0.6} \mathrm{Co}_{0.4} \mathrm{O}_{3-\delta}$ (LNC) infiltrated YSZ [21]. Furthermore, the $R_{p}$ values are comparable to those reported recently for high-performance cells using $\mathrm{Sm}_{0.5} \mathrm{Sr}_{0.5} \mathrm{CoO}_{3-\delta}$ (SSC) infiltrated $\mathrm{LSCF} / \mathrm{CGO}$ composite (e.g., $0.28 \Omega \mathrm{cm}^{2}$ at $750{ }^{\circ} \mathrm{C}$ ) [23] and $\mathrm{SrTi}_{0.3} \mathrm{Fe}_{0.63} \mathrm{Co}_{0.07} \mathrm{O}_{3-\delta}$ (e.g., $0.27 \Omega \mathrm{cm}^{2}$ at $750{ }^{\circ} \mathrm{C}$ ) [40]. With increasing the $\mathrm{H}_{2} \mathrm{O}$ content from $4 \%$ to $50 \%$, the $\mathrm{R}_{\mathrm{p}}$ decreases pronouncedly at corresponding temperatures (Fig. $5 \mathrm{c}$ and $5 \mathrm{e}$ ), to $0.09,0.12$, and $0.18 \Omega \mathrm{cm}^{2}$, respectively. The observed $\mathrm{R}_{\mathrm{p}}$ of $0.18 \Omega \mathrm{cm}^{2}$ at $700{ }^{\circ} \mathrm{C}$ is also lower than those reported for $\mathrm{Ni} / \mathrm{YSZ}$ fuel-electrodesupported cells using different oxygen electrodes under the same condition, including LSCF/CGO composite $\left(0.33 \Omega \mathrm{cm}^{2}\right)$ [10], SSC infiltrated YSZ $\left(0.66 \Omega \mathrm{cm}^{2}\right)$ [39], $\mathrm{Nd}_{2} \mathrm{NiO}_{4+\delta}$ (NNO) infiltrated $\mathrm{Zr}_{0.88} \mathrm{Sc}_{0.22} \mathrm{Ce}_{0.01} \mathrm{O}_{2.11}$ (SSZ) $\left(0.51 \Omega \mathrm{cm}^{2}\right)$ [41], and LSCF infiltrated YSZ (0.20 $\Omega \mathrm{cm}^{2}$ ) [22]. These EIS results demonstrate the high performance of the LSC infiltrated CGO oxygen electrode, and that this electrode is very suitable for the purpose.

To clarify the type of electrode processes and their contributions to $R_{p}$, the method based on calculating the distribution function of relaxation times (DRT) was applied in the EIS analysis. Fig. 5b, 5d, and 5f show the DRT plots calculated from the EIS data shown in Fig. 5a, 5c, and 5e, respectively. These DRT plots have a set of five distinct peaks denoted P1 to P5 from high to low frequency. Each peak represents an electrode process, and its integral area is a measure of the resistance of that process. Evidently from Fig. $5 \mathrm{~b}$ and $5 \mathrm{~d}$ the processes associated with P1 to P3 are characterized by a pronounced thermal activation while P4 and P5 are not sensitive to temperature. This strongly indicates that P1 to P3 correspond to the chemical and electrochemical processes in the electrodes and P4 and P5 are related to gas diffusion and 
conversion [42]. Fig. 5 f shows that $\mathrm{P} 2, \mathrm{P} 4$, and $\mathrm{P} 5$ are very sensitive to the ratio of $\mathrm{H}_{2} \mathrm{O}$ to $\mathrm{H}_{2}$ in the fuel electrode compartment while they are almost independent of gas change in the oxygen electrode. Thus, P2 is most likely associated with charge transfer processes at the triple phase boundaries (TPBs) of the fuel electrode; P4 represents the gas diffusion and the major contribution of P4 is from the fuel electrode; P5 is the gas conversion impedance in the fuel electrode [27, 43]. Furthermore, P1 is independent of any gas changes, and it is likely associated with the transport of oxygen anions through the ionic conducting networks in the electrodes [27, 43, 44]. Since the present cell has a highly ionic conducting CGO backbone based oxygen electrode, the major contribution of P1 is from the fuel electrode that has a YSZ network. The change of gas in the oxygen electrode compartment from air to pure $\mathrm{O}_{2}$ leads to a change in $\mathrm{P} 3$, indicating that P3 is likely related to the charge transfer processes of oxygen incorporation/evolution at the active sites of the oxygen electrode [27, 45]. The DRT results suggest that for the present cell with the Ni/YSZ fuel electrode and the nanostructured LSC infiltrated CGO oxygen electrode, the resistance of the fuel electrode dominates the total $R_{p}$ while the resistance of oxygen electrode is much smaller. 

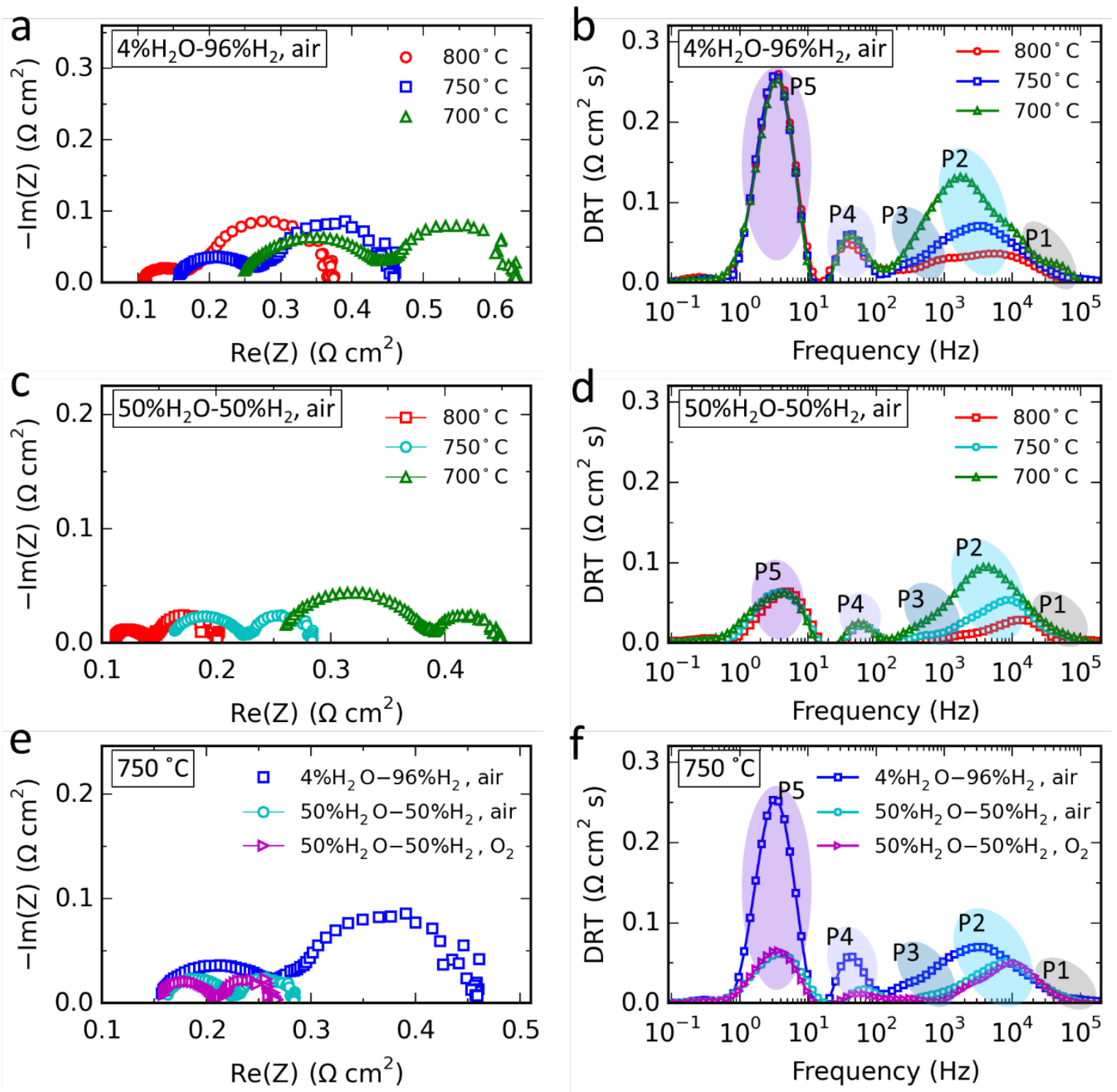

Fig. 5. Nyquist plots of EIS data recorded under OCV (a) at different temperatures with $4 \% \mathrm{H}_{2} \mathrm{O}-$ $96 \% \mathrm{H}_{2}$ fed to the fuel electrode and dry air to the oxygen electrode, (c) at different temperatures with $50 \% \mathrm{H}_{2} \mathrm{O}-50 \% \mathrm{H}_{2}$ fed to the fuel electrode and dry air to the oxygen electrode, and (e) at $750{ }^{\circ} \mathrm{C}$ with varying gas feeds to the electrodes. (b, $\left.\mathrm{d}, \mathrm{f}\right)$ Corresponding DRT plots of EIS data shown in (a), (c) and (e). 


\subsection{Durability}

The durability of the cell was evaluated under electrolysis condition with a constant applied current density of $0.5 \mathrm{~A} \mathrm{~cm}^{-2}$, and $90 \% \mathrm{H}_{2} \mathrm{O}-10 \% \mathrm{H}_{2}$ fed to the fuel electrode and pure $\mathrm{O}_{2}$ to the oxygen electrode. Fig. 6a shows the evolution of cell voltage with time and the trend of cell degradation. Only $86 \mathrm{~h}$ of durability data is shown, because the test was terminated involuntarily after $86 \mathrm{~h}$ due to a malfunction in the $\mathrm{H}_{2}$ supply, which led to the redox of the Ni/YSZ support thus damaging the cell structure. The degradation rate increases from $\sim 0.3$ to $\sim 0.6 \mathrm{mV} \mathrm{h}^{-1} \mathrm{in}$ the first $30 \mathrm{~h}$, then decreases towards $\sim 0.1 \mathrm{mV} \mathrm{h}^{-1}$ in the following $50 \mathrm{~h}$.

Fig. $6 \mathrm{~b}$ shows the Nyquist plots of the EIS data recorded under current during the durability test. The almost unaltered $R_{o h m}$ and the pronouncedly increased $R_{p}$ shows that the cell degradation processes occur mainly on the electrodes. Between each two of the spectra measured at every $20 \mathrm{~h}$, the $\mathrm{R}_{\mathrm{p}}$ of EIS data recorded at $20 \mathrm{~h}$ and $40 \mathrm{~h}$ exhibits the largest difference, in agreement with the evolution of degradation rate shown in Fig. 6a. Furthermore, among the five peaks of the DRT plots shown in Fig. 6c, P2 increases significantly, implying that the major degradation is from the Ni/YSZ fuel electrode. This degradation of Ni/YSZ fuel electrode during electrolysis operation has also been reported previously [38, 46-48]. It is difficult to precisely determine the evolution of the resistance of the LSC-CGO oxygen electrode (P3), because the oxygen electrode impedance is relatively small and with respect to time constants it is overlapping with P2. 

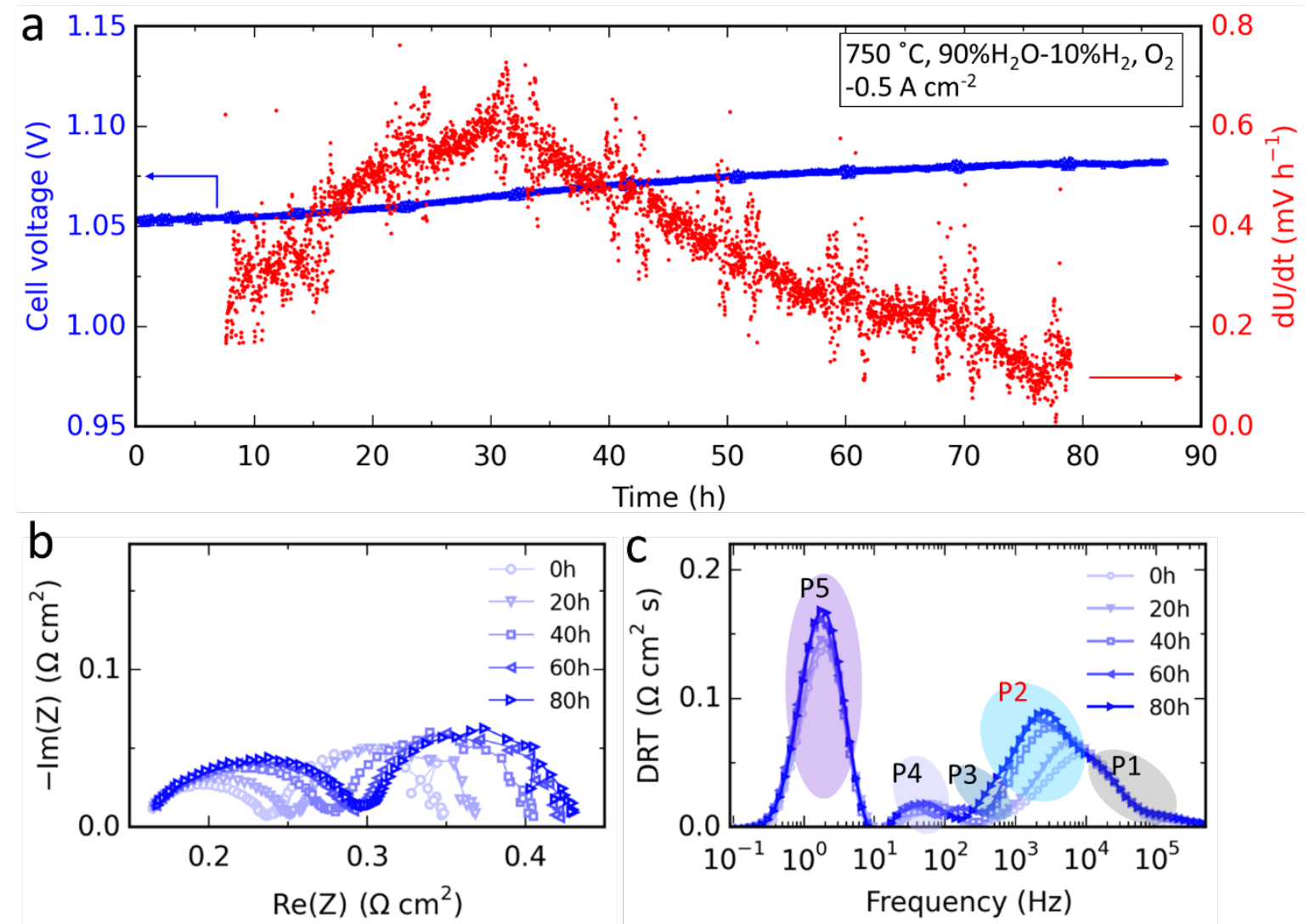

Fig. 6. Durability for steam electrolysis. (a) Evolution of cell voltage during short-term test under a constant current density of $0.5 \mathrm{~A} \mathrm{~cm}^{-2}$ at $750{ }^{\circ} \mathrm{C}$ with $90 \% \mathrm{H}_{2} \mathrm{O}-10 \% \mathrm{H}_{2}$ fed to the fuel electrode and pure $\mathrm{O}_{2}$ to the oxygen electrode. (b) Nyquist plots and (c) DRT plots of EIS data recorded under $0.5 \mathrm{~A} \mathrm{~cm}^{-2}$ during durability test.

These EIS data were further fitted with an equivalent circuit model shown in Fig. 7a. The model consists of four constant phase elements (RQ) and a modified Gerischer element (G), matching to the five different processes seen by DRT analysis, along with the $\mathrm{R}_{\text {ohm }}$ and an inductor (L) $[38,44]$. The fitting results are shown in Fig. 7b,c, Fig. S4 and Table S1. The fitted spectra of EIS data measured at $0 \mathrm{~h}$ and $80 \mathrm{~h}$ are shown in Fig. $7 \mathrm{~b}$ as examples. Fig. 7c summarizes the resistance values for each circuit element obtained from the fits. The value of $R_{3}$ 
(corresponding to the Gerischer element in the circuit model and the resistance of P3 of which includes the oxygen evolution steps at active sites in the oxygen electrode, $\mathrm{R}_{\mathrm{LSC}-\mathrm{CGO}}$ ) is only $0.010 \Omega \mathrm{cm}^{2}$ initially, demonstrating the high activity of the LSC infiltrated CGO oxygen electrode for the OER. Furthermore, the $\mathrm{R}_{3}$ has an increase of $0.002 \Omega \mathrm{cm}^{2}$ in $80 \mathrm{~h}$, contributing to less than $3 \%$ of the increase of ASR of cell $\left(0.082 \Omega \mathrm{cm}^{2}\right)$. While the increase of $\mathrm{R}_{1}$ (corresponding to the resistance for $\mathrm{P} 1$ of transport of oxygen anions, $\mathrm{R}_{\text {ion }}$ ) and $\mathrm{R}_{2}$ (corresponding to the resistance for P2 including the steam splitting processes at the TPBs of the fuel electrode, $\mathrm{R}_{\mathrm{Ni} / \mathrm{YSZ}}$ TPB) are $0.009 \Omega \mathrm{cm}^{2}$ and $0.046 \Omega \mathrm{cm}^{2}$, respectively, and contributes to $\sim 70 \%$ of the increase of ASR of cell. Albeit being encompassed with some uncertainty of fitting due to overlapping time scales, these results further confirm that the degradation of the cell is mainly from the Ni/YSZ fuel electrode, and demonstrates that also after $80 \mathrm{~h}$ the contribution from the LSC-CGO oxygen electrode is negligible. SEM micrographs of the LSC-CGO oxygen electrode before and after durability test are shown in Fig. 8. No obvious growth of the LSC nanoparticles is observed, consistent with the EIS results. It is worth noting that recently some encouraging progress has been made in insight into the degradation mechanism of Ni/YSZ fuel electrode during electrolysis and exploring strategies to reduce this degradation [27, 49-53]. For example, our laboratory has found that the durability of $\mathrm{Ni} / \mathrm{YSZ}$ fuel electrode can be significantly enhanced either by optimizing the microstructure of electrode [27] or modifying the electrode with CGO electrocatalysts $[49,50]$. 

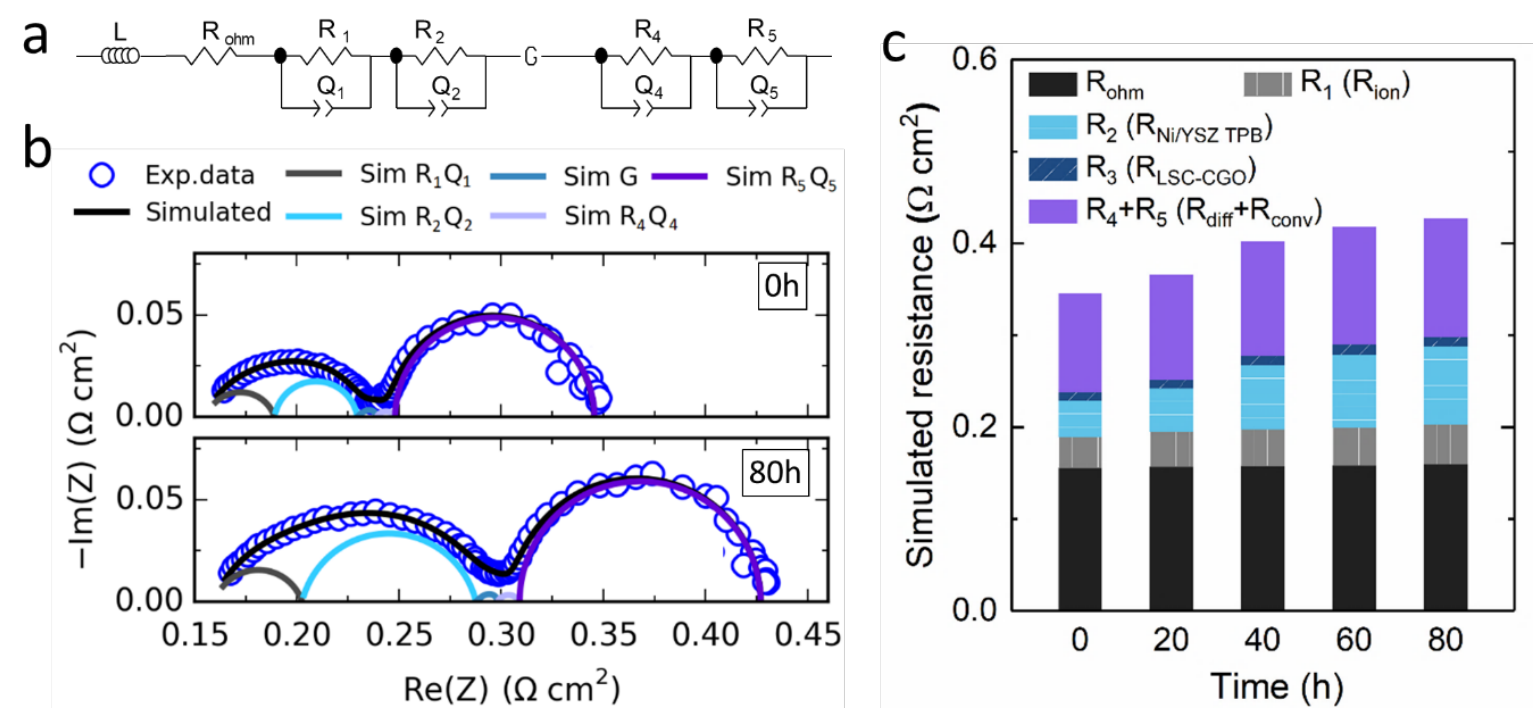

Fig. 7. (a) Equivalent circuit model for CNLS fit. (b) CNLS fits of EIS data recorded at $0 \mathrm{~h}$ and $80 \mathrm{~h}$ of durability test under $0.5 \mathrm{~A} \mathrm{~cm}^{-2}$ at $750{ }^{\circ} \mathrm{C}$ with $90 \% \mathrm{H}_{2} \mathrm{O}-10 \% \mathrm{H}_{2}$ fed to the fuel electrode and pure $\mathrm{O}_{2}$ to the oxygen electrode. (c) Resistances from the fitting results.
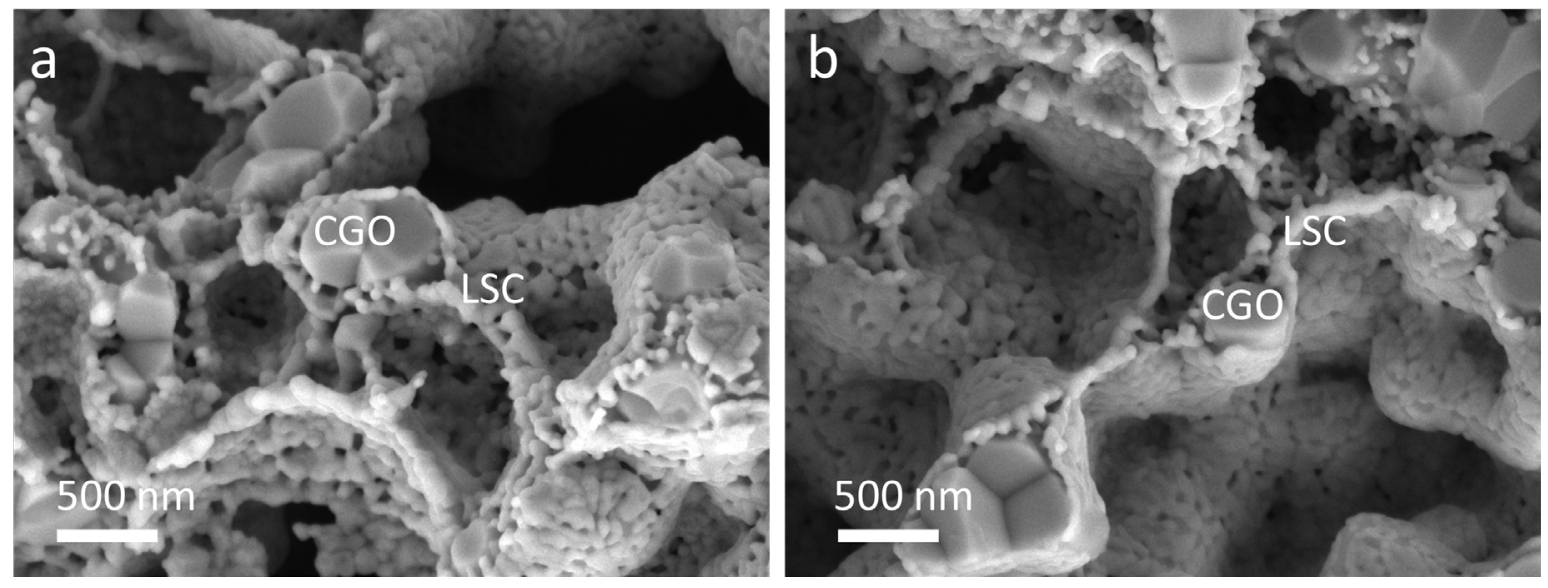

Fig. 8. Cross-sectional SEM images of LSC infiltrated CGO oxygen electrode for (a) before, and (b) after the durability test. 


\section{Conclusion}

In summary, we demonstrated the feasibility of preparing large-area SOCs by conventional ceramic processing techniques involving infiltrating LSC electrocatalysts into a pre-fired CGO porous backbone. The cell was examined at $4 \times 4 \mathrm{~cm}^{2}$ level (active area). In fuel cell mode, at a voltage of $0.6 \mathrm{~V}$, the cell delivered power densities of $1.34,1.08$, and $0.70 \mathrm{~W} \mathrm{~cm}^{-2}$ at 800,750 , and $700{ }^{\circ} \mathrm{C}$, respectively. These power densities were obtained with fuel and oxygen utilization of 65 and $71 \%$ at $800{ }^{\circ} \mathrm{C}, 52$ and $57 \%$ at $750{ }^{\circ} \mathrm{C}$, and 34 and $37 \%$ at $700{ }^{\circ} \mathrm{C}$, respectively. In electrolysis mode, the current densities at $1.3 \mathrm{~V}$ reached $1.37,1.07$, and $0.69 \mathrm{~A} \mathrm{~cm}^{-2}$ at 800,750 , and $700{ }^{\circ} \mathrm{C}$, respectively, corresponding to steam utilization of $76 \%, 60 \%$, and $38 \%$. The EIS results suggest that the LSC infiltrated CGO oxygen electrode has excellent activity for both the ORR and the OER and its durability when operated at $0.5 \mathrm{~A} \mathrm{~cm}^{-2}$ for steam electrolysis is good. The $\mathrm{R}_{\mathrm{LSC-CGO}}$ is only $0.010 \Omega \mathrm{cm}^{2}$ initially, and it has an increase of $0.002 \Omega \mathrm{cm}^{2}$ in $80 \mathrm{~h}$, contributing to less than $3 \%$ of the increase of ASR of cell $\left(0.082 \Omega \mathrm{cm}^{2}\right)$. The performance of the present cell is limited primarily by ohmic resistance and the resistance for electrochemical processes in the fuel electrode, of which the latter is responsible for the resistance degradation seen over the short durability test. Future work will focus on reducing the ohmic resistance and the fuel electrode polarization resistance, to improve both the cell performance and long-term durability.

\section{Acknowledgement}

The authors gratefully acknowledge the financial support by Danish TSO - Energinet.dk through the project "Towards Solid Oxide Electrolysis Plants in 2020" (ForskEL 2015-1-12276), EUDP through the project "Efficient Power2Gas Combining SOEC and Biomass Gasification" (EUDP 
no. 64017-0011), and Innovation Fund Denmark through project "Synfuel" (4106-00006B). X. F. Tong thanks the financial support from the China Scholarship Council (CSC201604910912). The authors also would like to thank H. Henriksen and M. Davodi for their assistance with cell testing, A. Hauch for help with EIS analysis, and E. Abdellahi for help with SEM sample preparation.

\section{References}

[1] S. Chu, A. Majumdar, Nature, 488 (2012) 294-303.

[2] J.T.S. Irvine, D. Neagu, M.C. Verbraeken, C. Chatzichristodoulou, C. Graves, M.B. Mogensen, Nat. Energy, 1 (2016) 15014.

[3] C. Graves, S.D. Ebbesen, S.H. Jensen, S.B. Simonsen, M.B. Mogensen, Nat. Mater., 14 (2015) 239-244.

[4] N. Ai, N. Li, S. He, Y. Cheng, M. Saunders, K. Chen, T. Zhang, S.P. Jiang, J. Mater. Chem. A, 5 (2017) 12149-12157.

[5] M.A. Laguna-Bercero, R. Campana, A. Larrea, J.A. Kilner, V.M. Orera, Fuel Cells, 11 (2011) 116-123.

[6] P. Kim-Lohsoontorn, D.J.L. Brett, N. Laosiripojana, Y.M. Kim, J.M. Bae, Int. J. Hydrogen Energy, 35 (2010) 3958-3966.

[7] V.A.C. Haanappel, J. Mertens, D. Rutenbeck, C. Tropartz, W. Herzhof, D. Sebold, F. Tietz, J Power Sources, 141 (2005) 216-226.

[8] A. Hauch, S.H. Jensen, S. Ramousse, M. Mogensen, J. Electrochem. Soc., 153 (2006) A1741. 
[9] T. Tsai, S.A. Barnett, Solid State Ionics, 93 (1997) 207-217.

[10] M.J. Lopez-Robledo, M.A. Laguna-Bercero, A. Larrea, V.M. Orera, J Power Sources, 378 (2018) 184-189.

[11] W. Wang, M. Mogensen, Solid State Ionics, 176 (2005) 457-462.

[12] G.M. Rupp, A.K. Opitz, A. Nenning, A. Limbeck, J. Fleig, Nat Mater, 16 (2017) 640-645.

[13] F. He, T. Wu, R. Peng, C. Xia, J Power Sources, 194 (2009) 263-268.

[14] Z. Shao, S.M. Haile, Nature, 431 (2004) 170-173.

[15] A. Jun, J. Kim, J. Shin, G. Kim, Angew. Chem. Int. Ed., 55 (2016) 12512-12515.

[16] M.A. Laguna-Bercero, H. Monzón, A. Larrea, V.M. Orera, J. Mater. Chem. A, 4 (2016) 1446-1453.

[17] C. Nicollet, A. Flura, V. Vibhu, A. Rougier, J.-M. Bassat, J.-C. Grenier, Int. J. Hydrogen Energy, 41 (2016) 15538-15544.

[18] D. Ding, X.X. Li, S.Y. Lai, K. Gerdes, M.L. Liu, Energy Environ. Sci., 7 (2014) 552-575.

[19] J.M. Vohs, R.J. Gorte, Adv. Mater., 21 (2009) 943-956.

[20] A.J. Samson, P. Hjalmarsson, M. Søgaard, J. Hjelm, N. Bonanos, J Power Sources, 216 (2012) 124-130.

[21] A. Chrzan, S. Ovtar, P. Jasinski, M. Chen, A. Hauch, J Power Sources, 353 (2017) 67-76.

[22] H. Fan, M. Keane, N. Li, D. Tang, P. Singh, M. Han, Int. J. Hydrogen Energy, 39 (2014) 14071-14078. 
[23] S.-i. Lee, J. Kim, J.-W. Son, J.-H. Lee, B.-K. Kim, H.-J. Je, H.-W. Lee, H. Song, K.J. Yoon, J Power Sources, 250 (2014) 15-20.

[24] J. Chen, F. Liang, D. Yan, J. Pu, B. Chi, S.P. Jiang, L. Jian, J Power Sources, 195 (2010) 5201-5205.

[25] S. Ovtar, A. Hauch, S. Veltzé, M. Chen, Electrochim. Acta, 266 (2018) 293-304.

[26] P.H. Larsen, K. Brodersen, U.S. Patent No. 8,790,847. 29 Jul. 2014.

[27] A. Hauch, K. Brodersen, M. Chen, M.B. Mogensen, Solid State Ionics, 293 (2016) 27-36.

[28] S.D. Ebbesen, C. Graves, A. Hauch, S.H. Jensen, M. Mogensen, J. Electrochem. Soc., 157 (2010) B1419-B1429.

[29] C. Graves, Ravdav, Data Analysis Software, Ver 0.97, 2012.

[30] A. Samson, M. Sogaard, R. Knibbe, N. Bonanos, J. Electrochem. Soc., 158 (2011) B650.

[31] Y. Hu, Y. Bouffanais, L. Almar, A. Morata, A. Tarancon, G. Dezanneau, Int. J. Hydrogen Energy, 38 (2013) 3064-3072.

[32] S. Liu, Q. Liu, J.-L. Luo, Acs Catal, 6 (2016) 6219-6228.

[33] S.D. Ebbesen, S.H. Jensen, A. Hauch, M.B. Mogensen, Chemical reviews, 114 (2014) 10697-10734.

[34] A. Tsoga, Solid State Ionics, 135 (2000) 403-409.

[35] A. Tsoga, A. Gupta, A. Naoumidis, P. Nikolopoulos, Acta Mater., 48 (2000) 4709-4714.

[36] A. Tsoga, A. Naoumidis, A. Gupta, D. Stöver, Mater. Sci. Forum, 308-311 (1999) 794-799. 
[37] H. Xu, K. Cheng, M. Chen, L. Zhang, K. Brodersen, Y. Du, J Power Sources, 441 (2019) 227152.

[38] P. Hjalmarsson, X. Sun, Y.-L. Liu, M. Chen, J Power Sources, 262 (2014) 316-322.

[39] H. Fan, M. Han, Faraday Discuss., 182 (2015) 477-491.

[40] S.-L. Zhang, H. Wang, M.Y. Lu, A.-P. Zhang, L.V. Mogni, Q. Liu, C.-X. Li, C.-J. Li, S.A. Barnett, Energy Environ. Sci., 11 (2018) 1870-1879.

[41] T. Chen, M. Liu, C. Yuan, Y. Zhou, X. Ye, Z. Zhan, C. Xia, S. Wang, J Power Sources, 276 (2015) 1-6.

[42] C. Graves, S.D. Ebbesen, M. Mogensen, Solid State Ionics, 192 (2011) 398-403.

[43] M. Chen, X. Sun, C. Chatzichristodoulou, S. Koch, P.V. Hendriksen, M.B. Mogensen, ECS Trans., 78 (2017) 3077-3088.

[44] A. Hauch, M. Marchese, A. Lanzini, C. Graves, J Power Sources, 377 (2018) 110-120.

[45] P. Hjalmarsson, X. Sun, Y.-L. Liu, M. Chen, J Power Sources, 223 (2013) 349-357.

[46] D. The, S. Grieshammer, M. Schroeder, M. Martin, M. Al Daroukh, F. Tietz, J. Schefold, A. Brisse, J Power Sources, 275 (2015) 901-911.

[47] M. Chen, Y.L. Liu, J.J. Bentzen, W. Zhang, X. Sun, A. Hauch, Y. Tao, J.R. Bowen, P.V. Hendriksen, J. Electrochem. Soc., 160 (2013) F883-F891.

[48] A. Hauch, S.D. Ebbesen, S.H. Jensen, M. Mogensen, J. Electrochem. Soc., 155 (2008) B1184.

[49] S. Ovtar, X. Tong, J.J. Bentzen, K.T.S. Thyden, S.B. Simonsen, M. Chen, Nanoscale, 11 (2019) 4394-4406. 
[50] X. Tong, S. Ovtar, K. Brodersen, P.V. Hendriksen, M. Chen, ACS Appl Mater Interfaces, 11 (2019) 25996-26004.

[51] M.B. Mogensen, A. Hauch, X. Sun, M. Chen, Y. Tao, S.D. Ebbesen, K.V. Hansen, P.V. Hendriksen, Fuel Cells, (2017).

[52] M.P. Hoerlein, M. Riegraf, R. Costa, G. Schiller, K.A. Friedrich, Electrochim. Acta, 276 (2018) 162-175.

[53] M. Trini, P.S. Jørgensen, A. Hauch, J.J. Bentzen, P.V. Hendriksen, M. Chen, J. Electrochem. Soc., 166 (2019) F158-F167. 